\title{
CREEP BEHAVIOR OF BORATE-TREATED STRANDBOARD: EFFECT OF ZINC BORATE RETENTION, WOOD SPECIES, AND LOAD LEVEL
}

\author{
Qinglin Wu ${ }^{1}$, Jong N. Lee ${ }^{2}$, Zhiyong Cai ${ }^{3}$, Dingguo Zhou ${ }^{4}$
}

\begin{abstract}
Creep performance of zinc borate-treated strandboard from southern pine (Pinus taeda L.) and red oak (Quercus falcata) was investigated at $25^{\circ} \mathrm{C}$ temperature and $65 \%$ relative humidity. It was shown that the borate treatment had some significant effect on creep deflection of the test panels, and the effect varied with wood species. There was no significant effect of creep loading on residual bending properties of treated strandboard under the stress levels used. The four element spring-dashpot creep model fitted the creep data well. The predicted creep deflection for a 10-year loading duration under both $15 \%$ and $40 \%$ stress levels met the National Design Specification for Wood Construction despite of the noticeable borate treatment effect on creep. Future work is needed to study the creep behavior under combined mechanical and moisture loadings for treated structural panels.
\end{abstract}

Keywords: Rheological behavior, creep, chemical treatment, OSB, zinc borate.

\section{INTRODUCTION}

Borate treated structural wood strand composites are developed for buildings where enhanced biological durability (e.g., termite resistance) is needed. During product development, short-term tests have been exclusively used to examine product performances including chemical compatibility, mechanical, and dimensional stability properties (Laks et al. 1988, Sean et al. 1999, Lee et al. 2004). Test results on treated oriented strandboard (OSB) have shown that boards bonded with both phenolic and isocyanate adhesives can have a reduction in panel strength upon the incorporation of borate compound. Thus, structural durability is a major concern for treated structural panels both in load-bearing (e.g., OSB shear wall, roof diaphragm, and I-beams) and non-load-bearing (e.g., OSB siding and sheathing) applications.

Borates are inorganic salts, which diffuse throughout composite with moisture movement, which could further deteriorate the adhesive bonding. Furthermore, powder borate sprayed on wood flakes during the blending process sometimes creates non-glued spots, which can adversely affect internal bond strength, panel stiffness, and strength under both short-term and long-term loadings (Creffield and Watson 2002, Gardner 2003, Kirkpatrick and Barnes 2006, Laks 2002). Soltis and Winandy (1988) and Winandy (1995) indicated that long-term performance of chemically treated wood was different from that of untreated wood. As a result, the application of current creep factor of untreated wood to the determination of the design value of chemically treated product should be revised. Designers, manufacturers, and consumers should be informed of performance requirements for borate treated OSB with the guideline for service life and deflection limits under long-term mechanical and changing environmental loading conditions.

Professor. School of Renewable Natural Resources. Louisiana State University Agricultural Center. Baton Rouge, LA 70803-6202

${ }^{2}$ Former Postdoctoral Researcher. School of Renewable Natural Resources. Louisiana State University Agricultural Center. Baton Rouge, LA 70803-6202

${ }_{3}^{3}$ Research Engineer+. Forest Products Laboratory, USDA Forest Service. One Gifford Pinchot Drive. Madison, WI 53726-2398

${ }^{4}$ Professor, College of Wood Science and Technology, Nanjing Forestry University, Nanjing, China 210037

Corresponding author: qwu@agcenter.lsu.edu

Received: 06.07. 2008. Accepted: 13.11.2008 
Extensive research has been conducted to investigate creep behavior of structural wood composite panels including plywood, waferboard, and OSB (e.g., Leichti and Tang 1987; Fridley et al. 1992; and Laufenberg et al. 1994). Information on creep behavior of the panel products was summarized by Bach (1993), Palka (1993), and Cheng et al. (1994). For OSB, some studies emphasized the effects of wood species and climatic conditions on its creep performance (Leichti 1986, Yeh 1990, Fridley et al. 1992), while others focused on the effect of resin type and press parameters on the creep (Lee 1999). The results of these studies have provided wood structural designers and technologists with information regarding to the long-term mechanical performance of structural composite panels. The information on treated composite is however, limited.

The development of creep models for wood began at least a century ago and many useful models have been presented (Lee 1999). Elastic springs and viscous dashpots in various combinations are commonly used to represent the viscoelastic behavior of the materials. Forms of the simplest viscoelastic models are the Maxwell, Kelvin, Linear, and Burger models (Gittus 1975), as shown in Figure 1. Among them, a four-element spring and dashpot model (known as Burger body) has been used to predict the creep of wood products well. The mathematical expression of the model is

$$
\varepsilon(t)=\varepsilon_{e}+\varepsilon_{k}+\varepsilon_{v}=\frac{\sigma}{K_{e}}+\frac{\sigma}{K_{k}}\left[1-e^{\left(-\frac{K_{k} t}{\eta_{k}}\right)}\right]+\frac{\sigma t}{\eta_{v}}
$$

where: $\varepsilon, \varepsilon_{e}, \varepsilon_{k}$, and $\varepsilon_{v}$ are, respectively, total strain, elastic strain, viscoelastic strain, and viscoplastic strain, $\sigma$ is applied stress, $K_{e}$ is elastic constant of the Hookean spring, $K_{k}$ is delayed elastic constant of the spring element in the Kelvin body, $\eta_{k}$ is viscous constant of the dashpot in the Kelvin body, and $\eta_{\text {, }}$ is viscous constant for the permanent deflection. Although the Burger's model has been widely used for many wood products, applying the model to chemically treated OSB has not been attempted.

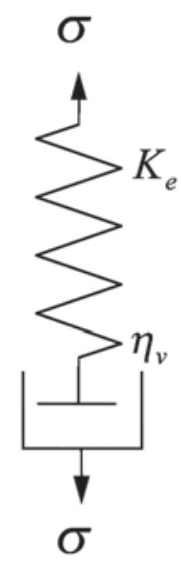

Maxwell

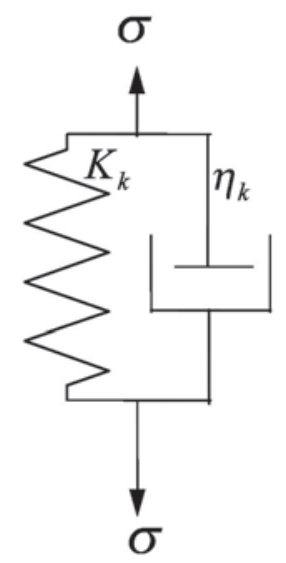

Kelvin

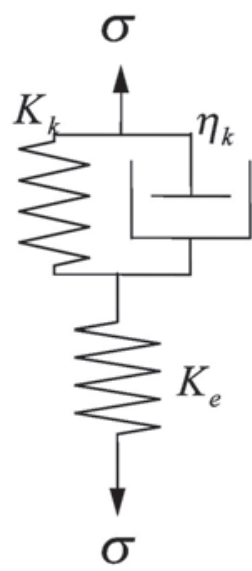

Linear

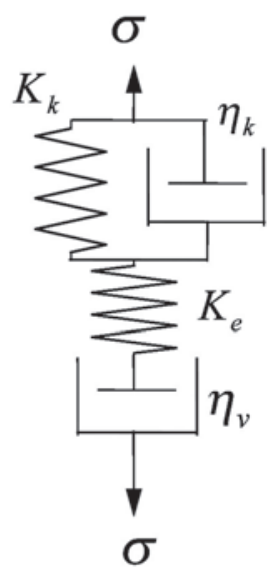

Burger

Figure 1. Commonly-used creep models for a viscoelastic material. 
The objectives of this study were a) to experimentally evaluate creep properties of borate treated OSB under the controlled environmental condition; b) to model the observed creep behavior using the Burger's model; and c) to predict long-term creep performance of the OSB. Future publications will deal with creep performance of the OSB under combined mechanical and moisture loadings.

\section{MATERIAL AND METHODS}

Strandboard manufacuring. - Southern pine (Pinus taeda L.) and red oak (Quercus falcata) lumber $(2.54-\mathrm{cm}$ thick with random width) was obtained from a local saw mill. The lumber was cross-cut into 15.2-cm long sections, from which 7.6 (long) x 0.064 (thick)-cm flakes were produced using a laboratory disc flaker. The flakes were then dried to about $4 \%$ moisture content. The dried flakes were blended with $4 \%$ liquid phenol-formaldehyde resin and $1 \%$ wax based on oven-dry flake weight. During blending process, powder zinc borate was sprayed directly onto flakes in the blender using a flexible plastic tube and regulated air at three different target loading levels of $0,1.5$, and $3.0 \%$ based on the oven-dry flake weight. Flakes (55.88- x $50.8-\mathrm{cm}$ in size) were hand-formed into randomly-oriented mats. Each mat was then hot pressed under a press schedule with one-minute closing time and fiveminute curing time at a temperature of $200^{\circ} \mathrm{C}$. The target density and thickness were $0.8 \mathrm{~g} / \mathrm{cm}^{3}$ and 12.7 $\mathrm{mm}$, respectively. Six different board types ( 2 species and 3 borate levels) at constant density with 4 replications for each type were produced.

Creep sample preparation. - Two 36.56- (long) x 7.62- (wide) x 1.27 -cm (thick) specimens were cut from each panel, which gave eight specimens per board type and a total of 48 specimens. All samples were conditioned under $25^{\circ} \mathrm{C}$ and $65 \% \mathrm{RH}$ for at least four weeks prior to testing. Four specimens from each board type were randomly selected as control samples for the evaluation of static bending modulus of rupture (MOR) and the other four were used for the creep test. Mean MOR value of the four control specimens for each board type was used in determining designated stress levels (SLs) for the corresponding creep test samples. Two stress levels (15\% and $40 \%$ of MOR) were used for each board type. The control samples were tested according to the ASTM standard D-1037 (1999). Chemical analysis was done to determine actual boron loading in the panel expressed as boric acid equivalent (BAE) following the procedure used by Lee et al. (2004).

Creep testing. - A 24-position load frame with a dead weight loading system was constructed for creep testing (Figure 2). The frame has two levels with twelve samples positioned side by side at each level. Each specimen was supported by two short metal pipes (one at each end). Dead load was applied to each specimen at the central point of the span. One linear variable differential transducer (LVDT) traveling to each individual specimen with a miniature carriage on two precision stainless steel rods was used to measure deflections for all samples at each level. A reference plate for each sample was used to reference the LVDT measurement each time so that the deflection was accurately determined. The deflection data (D in Figure 2) were collected through a Strawberry-Tree DataShuttle ${ }^{\circledR}$ card controlled by a specially designed Visual Basic program. The program enables a three-way communication with the WorkBench ${ }^{\circledR}$ program (data acquisition) and Microsoft Excel ${ }^{\circledR}$ (data processing) using dynamic data exchange (DDE) tools. The entire creep testing was conducted in an environment chamber with controlled temperature $\left(25^{\circ} \mathrm{C}\right)$ and relative humidity $(65 \% \mathrm{RH})$. The samples were under their designated constant loads for two months and unloaded for three weeks. The deflection data of each specimen as well as temperature, $\mathrm{RH}$, and weight of a special MC specimen were monitored daily. After creep testing, all samples were tested for their residual strength and stiffness following the same ASTM standard for static bending test. 


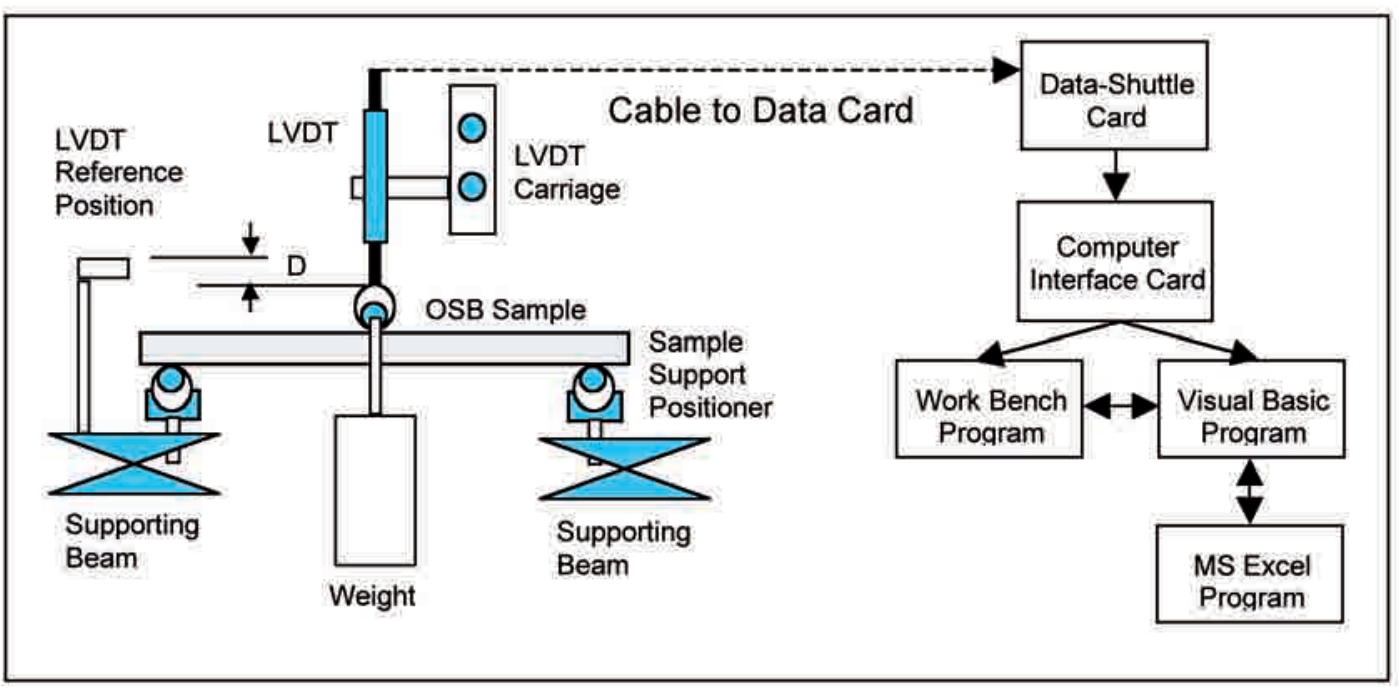

Figure 2. Schematic of the test setup for creep measurements.

Data analysis and creep modeling. In order to fit the Burger's model, the collected deflection data were converted to strain using the following equation:

$$
\varepsilon(t)=-\kappa y(t)=\frac{M}{E I} y(t)
$$

where: $\varepsilon$ is the axial strain of the outermost layer in the specimen, $\kappa$ is the curvature of the deflected beam, $M$ is the applied bending moment, EI is the stiffness of the specimen, and $y(t)$ is the bending deflection at a given time. It was assumed that stress-strain relationship was linear and the cross section remained the same during the bending test. This assumption was approximately true and acceptable for wood products, especially when they were under low bending stresses (Cai et al. 2002).

A nonlinear curve fitting technique was successfully used to determine the Burger's model parameters (Pierce and Dinwoodie 1977). The approximation of Equation 1 with a regression model has following form with an error term:

$$
\varepsilon(t)=\beta_{1}+\beta_{2}\left[1-\exp \left(-\beta_{3} t\right)\right]+\beta_{4} t+\text { error }
$$

where: $\beta_{l}, \beta_{2}, \beta_{3}$, and $\beta_{4}$ were the estimated variables for $\sigma / K_{e^{\prime}} \sigma / K_{k}, K_{k} / \eta_{k^{\prime}}$, and $\sigma / \eta_{v}$, respectively. These variables can be determined by minimizing the error sum of squares:

$$
S\left(\beta_{1}, \beta_{2}, \beta_{3}, \beta_{4}\right)=\sum_{i=1}^{n}\left[\varepsilon_{i}\left(t_{i}\right)-\beta_{1}-\beta_{2}\left[1-\exp \left(-\beta_{3} t_{i}\right)\right]-\beta_{4} t_{i}\right]^{2}
$$

where $\varepsilon_{i}(\mathrm{t})$ represents an creep strain observed at time $t$. Due to the nonlinear relationship between error of $S$ and $\beta_{3}$, an iterative procedure with an initial estimate of $\beta_{3}$ had to be used (Pierce and Dinwoodie 1977). A computer program based on the least square technique was developed to implement the above algorithm for data fitting. 
The characterized model was used to predict the creep and recovery performances of the strandboard. The predicted values were then compared with the actual experimental data, showing that the fitting procedures were acceptable. Relative creep defined as

$$
\text { Relative Creep }=\frac{\text { Deflection }(t)-\text { Initial Deflection }\left(t_{o}\right)}{\text { Initial Deflection }\left(t_{o}\right)} \times 100 \%
$$

over an extended loading period was also predicted using the model to investigate the long-term creep performance of the strandboard. The initial deflection was taken 5 seconds after the load was applied to each specimen. Finally, a two-way statistical analysis of variation (ANOVA) was used to analyze the effect of stress and borate retention level on the creep behavior and the residual bending properties.

\section{RESULTS AND DISCUSSION}

\section{Creep Properties}

Experimental data. Static bending properties and densities of control samples at various borate loading levels are summarized in Table 1. Actual BAE in the samples varied among panels for each species group. Southern pine boards had higher BAE values than the red oak boards. The average densities of groups under different treatments for each species were slightly different due to inherent mat structure variation for strand-type composites. The overall mean density for all sample groups was $0.83 \mathrm{~g} / \mathrm{cm}^{3}$ for southern pine and $0.84 \mathrm{~g} / \mathrm{cm}^{3}$ for red oak. Figure 3 shows mean creep-deflection curves representing given stress and borate levels for southern pine (a) and red oak (b) specimens. 

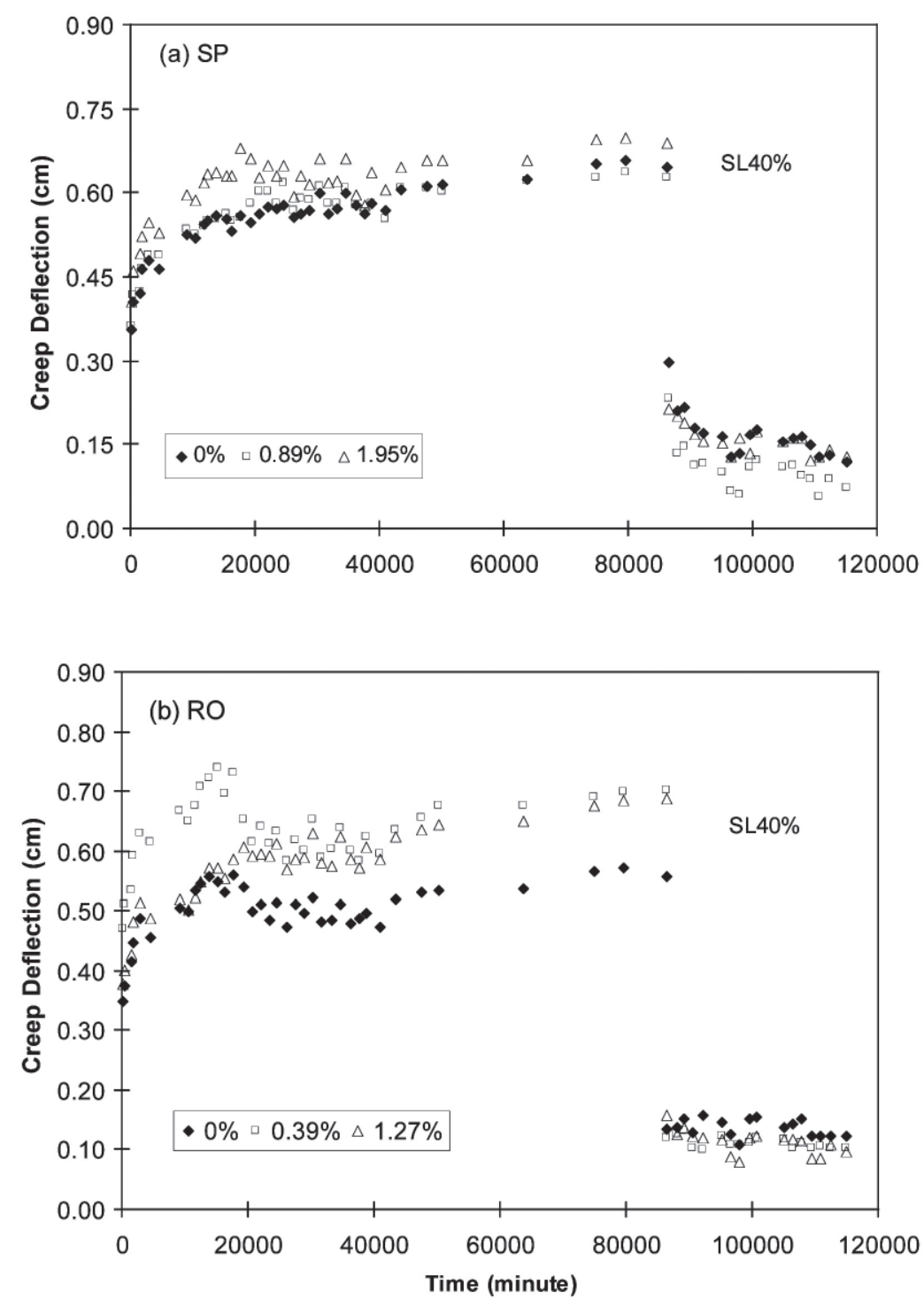

Figure 3. Typical creep-deflection curves under the $40 \%$ stress level and different borate treatments for southern pine (a) and red oak (b) strandboard.

Average values of creep deflection characteristics (i.e., instantaneous deflection, maximum deflection, instantaneous recovery deflection, and permanent deflection) are summarized in Table 2. While there were daily variations in creep deflections during the creep test in all samples, the trends of typical creep deflection curves were clearly observed. All creep samples showed relatively large creep deflections and permanent deformations under the two-month constant loading. Statistical analyses of the means and standard deviations (at the 5\% significance level) were performed to examine possible effects of stress level, species, and borate treatment on the creep behavior. The analysis results are shown in Table 3. 
Table 1. A summary of basic properties of test samples.

\begin{tabular}{|c|c|c|c|c|c|c|c|c|c|}
\hline \multirow{3}{*}{$\begin{array}{l}\text { Wood } \\
\text { Species }\end{array}$} & \multirow{3}{*}{$\begin{array}{l}\text { BAE }^{1} \\
(\%)\end{array}$} & \multicolumn{2}{|c|}{ Initial Value $^{2}$} & \multicolumn{2}{|c|}{ Stress Level $^{3}$} & \multicolumn{4}{|c|}{ Residual Value $^{4}$} \\
\hline & & \multirow{2}{*}{$\begin{array}{l}\text { MOE } \\
(\mathrm{GPa})\end{array}$} & \multirow{2}{*}{$\begin{array}{l}\text { MOR } \\
(\mathrm{MPa})\end{array}$} & \multirow{2}{*}{$\begin{array}{l}\text { SL15 } \\
(\mathrm{MPa})\end{array}$} & \multirow{2}{*}{$\begin{array}{l}\text { SL40 } \\
(\mathrm{MPa})\end{array}$} & \multicolumn{2}{|c|}{ MOE (GPa) } & \multicolumn{2}{|c|}{ MOR (MPa) } \\
\hline & & & & & & SL15 & SL40 & SL15 & SL40 \\
\hline \multirow{3}{*}{$\begin{array}{l}\text { Southern } \\
\text { Pine }\end{array}$} & 0 & $\begin{array}{l}5.86 \\
(0.14)\end{array}$ & $\begin{array}{l}41.1 \\
(8.5)\end{array}$ & 6.2 & 16.4 & $\begin{array}{l}4.41 \\
(0.39)\end{array}$ & $\begin{array}{l}5.04 \\
(0.21)\end{array}$ & $\begin{array}{l}30.7 \\
(1.7)\end{array}$ & $\begin{array}{l}39.9 \\
(5.0)\end{array}$ \\
\hline & 0.89 & $\begin{array}{l}5.25 \\
(0.10)\end{array}$ & $\begin{array}{l}32.9 \\
(4.5)\end{array}$ & 4.9 & 13.2 & $\begin{array}{l}4.72 \\
(0.31)\end{array}$ & $\begin{array}{l}4.97 \\
(0.31)\end{array}$ & $\begin{array}{l}31.2 \\
(5.2)\end{array}$ & $\begin{array}{l}37.1 \\
(4.5)\end{array}$ \\
\hline & 1.95 & $\begin{array}{l}5.47 \\
(0.04)\end{array}$ & $\begin{array}{l}36.2 \\
(3.3)\end{array}$ & 5.4 & 14.5 & $\begin{array}{l}5.40 \\
(0.07)\end{array}$ & $\begin{array}{l}4.79 \\
(0.20)\end{array}$ & $\begin{array}{l}37.8 \\
(5.2)\end{array}$ & $\begin{array}{l}37.1 \\
(4.6)\end{array}$ \\
\hline \multirow{3}{*}{ Red Oak } & 0 & $\begin{array}{l}6.30 \\
(0.09)\end{array}$ & $\begin{array}{l}47.1 \\
(7.3)\end{array}$ & 7.1 & 18.8 & $\begin{array}{l}4.05 \\
(0.11)\end{array}$ & $\begin{array}{l}4.62 \\
(0.13)\end{array}$ & $\begin{array}{l}25.8 \\
(4.2)\end{array}$ & $\begin{array}{l}34.1 \\
(1.8)\end{array}$ \\
\hline & 0.69 & $\begin{array}{l}6.45 \\
(0.11)\end{array}$ & $\begin{array}{l}49.6 \\
(10.7)\end{array}$ & 7.4 & 19.8 & $\begin{array}{l}6.36 \\
(0.51)\end{array}$ & $\begin{array}{l}5.89 \\
(0.63)\end{array}$ & $\begin{array}{l}44.9 \\
(2.2)\end{array}$ & $\begin{array}{l}40.0 \\
(3.1)\end{array}$ \\
\hline & 1.27 & $\begin{array}{l}5.35 \\
(0.04)\end{array}$ & $\begin{array}{l}38.9 \\
(5.1)\end{array}$ & 5.8 & 15.6 & $\begin{array}{l}5.94 \\
(0.78)\end{array}$ & $\begin{array}{l}6.91 \\
(0.34)\end{array}$ & $\begin{array}{l}38.9 \\
(6.5)\end{array}$ & $\begin{array}{l}52.0 \\
(2.2)\end{array}$ \\
\hline
\end{tabular}

${ }^{1}$ BAE-boric Acid Equivalent.

${ }^{2}$ Initial value from the control samples. Values listed in parenthesis are standard derivation.

${ }^{3}$ Stress level (SL) based on the initial MOR value. SL15=15\% MOR; SL40=40\%MOR.

${ }^{4}$ Residual values after two-month creep test.

Table 2. Creep and recovery data for treated strandboard.

\begin{tabular}{|c|c|c|c|c|c|c|}
\hline \multirow[t]{2}{*}{ Species } & \multirow{2}{*}{$\begin{array}{l}\mathrm{SL}^{1} \\
(\%)\end{array}$} & \multirow{2}{*}{$\begin{array}{l}\text { BAE }^{2} \\
(\%)\end{array}$} & \multicolumn{2}{|c|}{ Creep } & \multicolumn{2}{|c|}{ Recovery } \\
\hline & & & $\begin{array}{l}\mathrm{ID}^{3} \\
(\mathrm{~cm})\end{array}$ & $\begin{array}{l}\mathrm{MD}^{3} \\
(\mathrm{~cm})\end{array}$ & $\begin{array}{l}\mathrm{IRD}^{3} \\
(\mathrm{~cm})\end{array}$ & $\begin{array}{l}\mathrm{PD}^{3} \\
(\mathrm{~cm})\end{array}$ \\
\hline \multirow{6}{*}{$\begin{array}{l}\text { Southern } \\
\text { Pine }\end{array}$} & \multirow{3}{*}{15} & 0.00 & $0.133(0.020)$ & $0.292(0.001)$ & $0.158(0.002)$ & $0.076(0.000)$ \\
\hline & & 0.89 & $0.133(0.001)$ & $0.292(0.021)$ & $0.208(0.018)$ & $0.046(0.007)$ \\
\hline & & 1.95 & $0.146(0.017)$ & $0.335(0.005)$ & $0.201(0.031)$ & $0.046(0.005)$ \\
\hline & \multirow{3}{*}{40} & 0.00 & $0.358(0.014)$ & $0.661(0.209)$ & $0.348(0.032)$ & $0.121(0.035)$ \\
\hline & & 0.89 & $0.364(0.008)$ & $0.639(0.082)$ & $0.397(0.029)$ & $0.073(0.050)$ \\
\hline & & 1.95 & $0.408(0.026)$ & $0.700(0.034)$ & $0.476(0.003)$ & $0.130(0.044)$ \\
\hline \multirow{6}{*}{ Red Oak } & \multirow{3}{*}{15} & 0.00 & $0.145(0.011)$ & $0.266(0.159)$ & $0.167(0.031)$ & $0.049(0.029)$ \\
\hline & & 0.69 & $0.163(0.045)$ & $0.318(0.036)$ & $0.193(0.045)$ & $0.060(0.011)$ \\
\hline & & 1.27 & $0.230(0.002)$ & $0.431(0.014)$ & $0.330(0.003)$ & $0.051(0.009)$ \\
\hline & \multirow{3}{*}{40} & 0.00 & $0.351(0.002)$ & $0.574(0.009)$ & $0.421(0.001)$ & $0.124(0.018)$ \\
\hline & & 0.69 & $0.471(0.016)$ & $0.702(0.107)$ & $0.580(0.038)$ & $0.105(0.004)$ \\
\hline & & 1.27 & $0.379(0.021)$ & $0.690(0.145)$ & $0.530(0.016)$ & $0.098(0.101)$ \\
\hline
\end{tabular}

${ }^{1}$ Stress level (SL) based on the initial MOR value. SL15=15\% MOR; SL40=40\%MOR.

${ }^{2}$ BAE-boric Acid Equivalent.

${ }^{3} \mathrm{ID}=$ Instantaneous deflection, $\mathrm{MD}=$ Maximum deflection, $\mathrm{IRD}=$ Instantaneous recovery deflection, and $\mathrm{PD}=$ Permanent deflection. Values listed in parenthesis are standard derivation. 
Table 3. Creep model parameters with coefficient of variation shown in parentheses.

\begin{tabular}{clllllll}
\hline \hline \multirow{2}{*}{$\begin{array}{l}\mathrm{SL}^{1} \\
(\%)\end{array}$} & $\begin{array}{l}\text { Model } \\
\text { Parameters }\end{array}$ & \multicolumn{2}{l}{ Southern pine } & \multicolumn{3}{l}{ Red oak } \\
\cline { 2 - 8 } & $0.0 \%^{2}$ & $0.89 \%$ & $1.95 \%$ & $0.0 \%$ & $0.69 \%$ & $1.27 \%$ \\
\hline \hline \multirow{3}{*}{15} & $\mathrm{~K}_{\mathrm{e}}(\mathrm{GPa})$ & 4.338 & 4.498 & 4.645 & 3.966 & 4.947 & 4.437 \\
\cline { 2 - 8 } & $\mathrm{K}_{\mathrm{k}}(\mathrm{GPa})$ & 14.210 & 15.070 & 9.729 & 16.510 & 12.540 & 8.121 \\
\cline { 2 - 8 } & $\eta_{\mathrm{k}} 10^{2}(\mathrm{GPa}-\mathrm{min})$ & 2.602 & 2.195 & 2.524 & 3.545 & 4.652 & 3.771 \\
\cline { 2 - 8 } & $\eta_{\mathrm{v}} 10^{8}(\mathrm{Gpa}-\mathrm{min})$ & 13.120 & 6.176 & 1.959 & 44.110 & 49.600 & 8.701 \\
\hline \multirow{3}{*}{40} & $\mathrm{~K}_{\mathrm{e}}(\mathrm{GPa})$ & 3.996 & 4.393 & 4.426 & 5.534 & 5.033 & 6.148 \\
\cline { 2 - 8 } & $\mathrm{K}_{\mathrm{k}}(\mathrm{GPa})$ & 8.361 & 7.228 & 7.671 & 13.320 & 7.063 & 6.751 \\
\cline { 2 - 8 } & $\eta_{\mathrm{k}} 10^{2}(\mathrm{GPa}-\min )$ & 3.887 & 1.843 & 2.080 & 5.455 & 11.270 & 4.146 \\
\cline { 2 - 8 } & $\eta_{\mathrm{v}} 10^{8}(\mathrm{GPa}-\mathrm{min})$ & 1.912 & 36.090 & 84.620 & 2.409 & 99.200 & 25.280 \\
\hline \hline
\end{tabular}

${ }^{1}$ SL-stress level.

${ }^{2}$ BAE-boric Acid Equivalent.

Borate treatment effect. The effect of borate treatments on the creep deflection of tested strandboard samples varied with wood species. For red oak, the effect of borate level on creep deflection was significant for the entire period of loading as shown in Figure $4 \mathrm{~b}$ and Table 3. The effect of borate on southern pine samples was quite different. No significant effect on instantaneous deflection (ID) of southern pine samples was observed (Figure 4a). When the duration of load increased, the effect became obvious and after two month loading the effect on the maximum creep and permanent deflections (PD) was significant under low stress level $(15 \%)$. The exact mechanism of different creep behavior of the two species after borate treatment was unclear. It was probably due to the different chemical reactions between borate and extractives in different flakes and the difference in anatomy and tissue types between the two species. It could also be due to the random nature of the non-glued spots caused by the borate powder sprayed on the flakes during the blending process. 

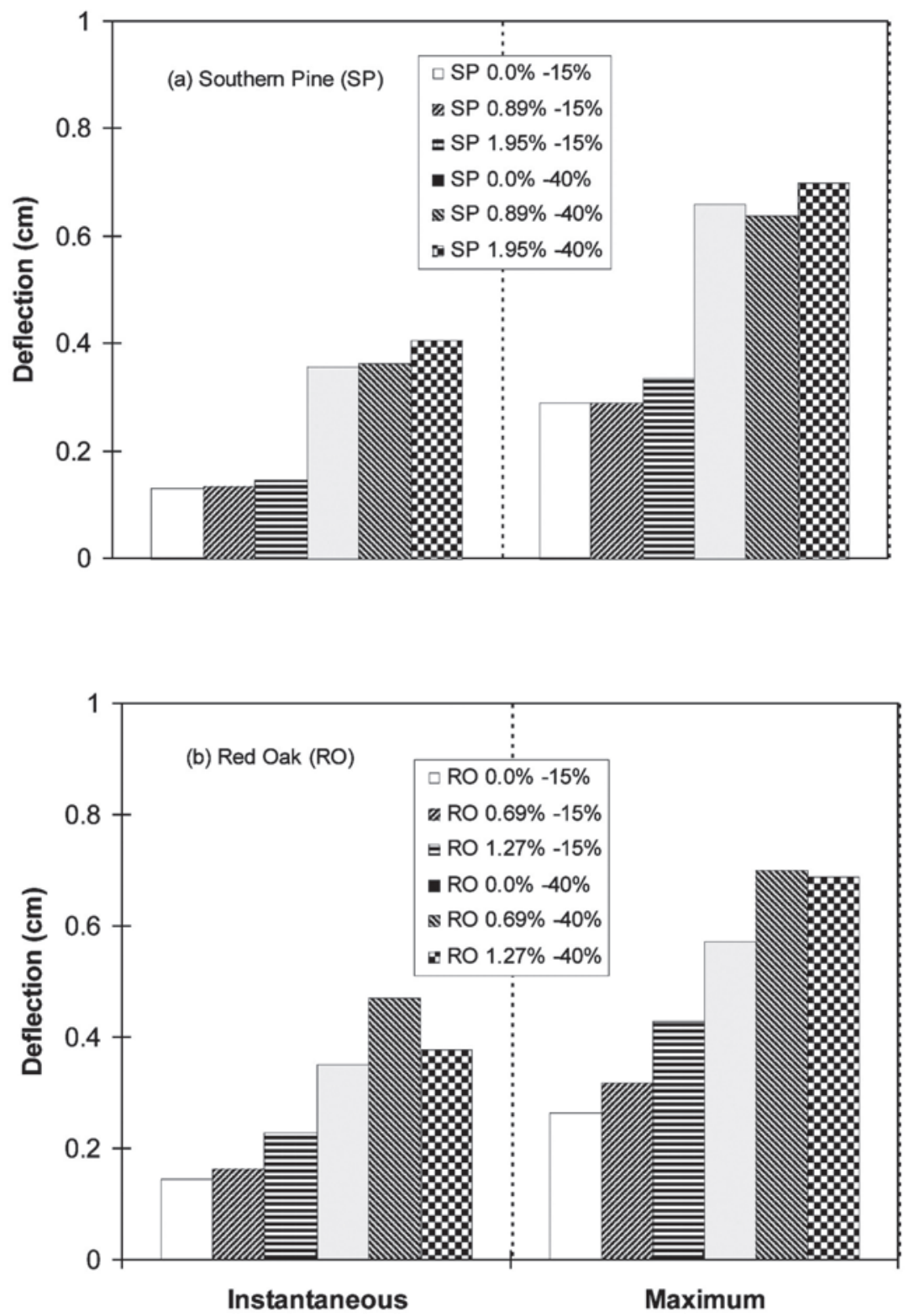

Figure 4. Mean instantaneous and maximum deflections for southern pine (a) and red oak (b) under different borate and stress levels. 
Species effect. The results showed that species effect on creep performance was different (Table 3). Species effect was not significant on ID and PD, but was significant on the maximum deflection (MD) and instantaneous recovery deflection (IRD). Close examination of MD (Table 4) revealed that without borate treatment southern pine strandboard samples exhibited larger average MD values than red oak. However, with the borate treatment most red oak samples had large MD values. This again indicated that creep performance (i.e., MD) of different species changed differently after borate treatment.

Stress level effect. The stress level had significant effects on creep behaviors as expected for all tested groups. Increasing stress level increased instantaneous and creep deflections (Figure 4 and Table $3)$. The stress level also interacted with the borate effect on creep performances. For southern pine, borate effect on MD was significant under low stress level, but under high stress level (40\%) borate treatment effect on MD (Figure 4a) was mixed with MD decreasing (borate level of $1.5 \%$ ) and MD increasing (borate level of 3.0\%).

\section{Creep strain modeling}

Figures $5 \mathrm{a}$ and $5 \mathrm{~b}$ show typical curves of experimental and predicted strains for southern pine and red oak samples under different stress levels, respectively. The agreement of experimental creep strains and predicted strains indicated that the Burger creep model could be used to describe the creep behavior under different treatments. The average model parameters for each group are shown in Table 4. The parameter of $\mathrm{K}_{\mathrm{e}}$, which represents majority of modulus of elasticity (MOE), was in the range of 3.996 to $4.645 \mathrm{GPa}$ for southern pine strandboard and of 3.966 to $6.148 \mathrm{GPa}$ for red oak. These $\mathrm{K}_{\mathrm{e}}$ values were about $28 \%$ less than the average MOE values of the control samples. The differences were due to lack of consideration of the $\mathrm{K}_{k}$, which is the delayed elastic constant of the spring element in the Kelvin body (Figure 1). Two species did not show a significant difference of $\mathrm{K}_{\mathrm{e}}$ at the $15 \% \mathrm{SL}$, but the red oak group showed slightly higher values at the $40 \%$ SL. Comparisons of other three parameters showed that red oak groups also had higher values than southern pine groups. 

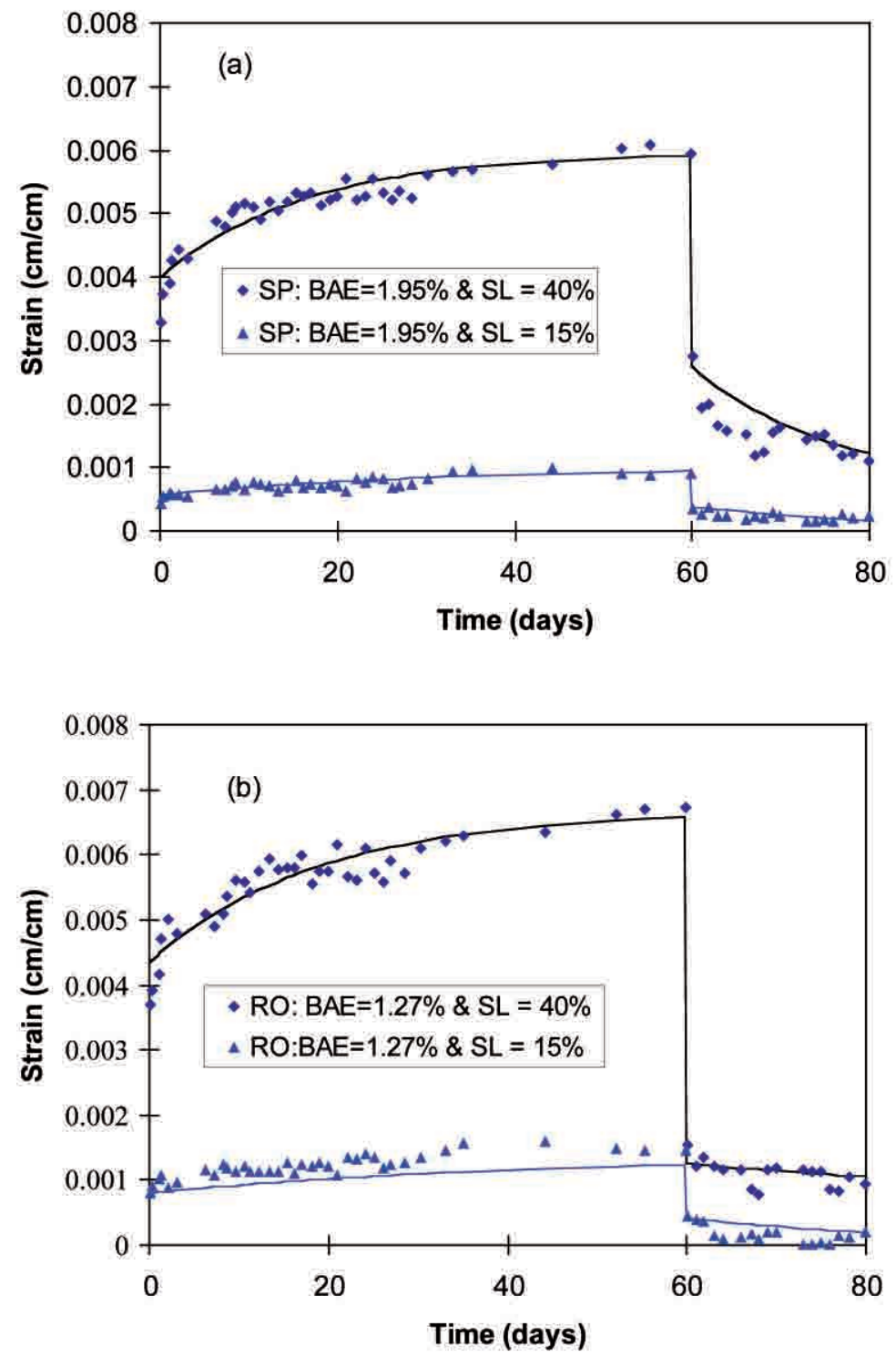

Figure 5. Typical curves of experimental and predicted strains under 15\% and $40 \%$ stress levels for (a) southern pine and (b) red oak strandboard.

Based on the average model parameters in Table 4, the creep performance under long term duration of load was estimated for the two species under different treatments (Figures 6a and 6b). At low stress level (15\%), the trends that creep deflections increased as the duration of load increased were very similar for the two species regardless of different borate treatments. NDS (AF\&PA 2001) requires that total deflection of wood structural panels under long term loading in dry service condition be within two times the instantaneous deflection, which is equivalent to $100 \%$ relative creep. Figures $6 \mathrm{a}$ and $6 \mathrm{~b}$ show that most of the estimated relative creeps after 20 years are less than $100 \%$, except for the group of southern pine specimens $(112 \%)$ treated with zinc borate $(1.95 \% \mathrm{BAE})$ and loaded at $15 \%$ stress level. If the duration of loading is 10 years, the predicted relative creeps of all tested OSB samples satisfy the NDS requirement. It should be pointed out that the creep performance of treated strandboard samples was tested under the controlled constant environmental conditions. Under changing or high 
RH conditions, the relative creep of wood composite panels is expected to be mush higher (Bach 1993, Lee 1999). Thus, for strandboard treated by different types of borate compounds to become market acceptable products, their long term loading performance under different service environments need to be further investigated.
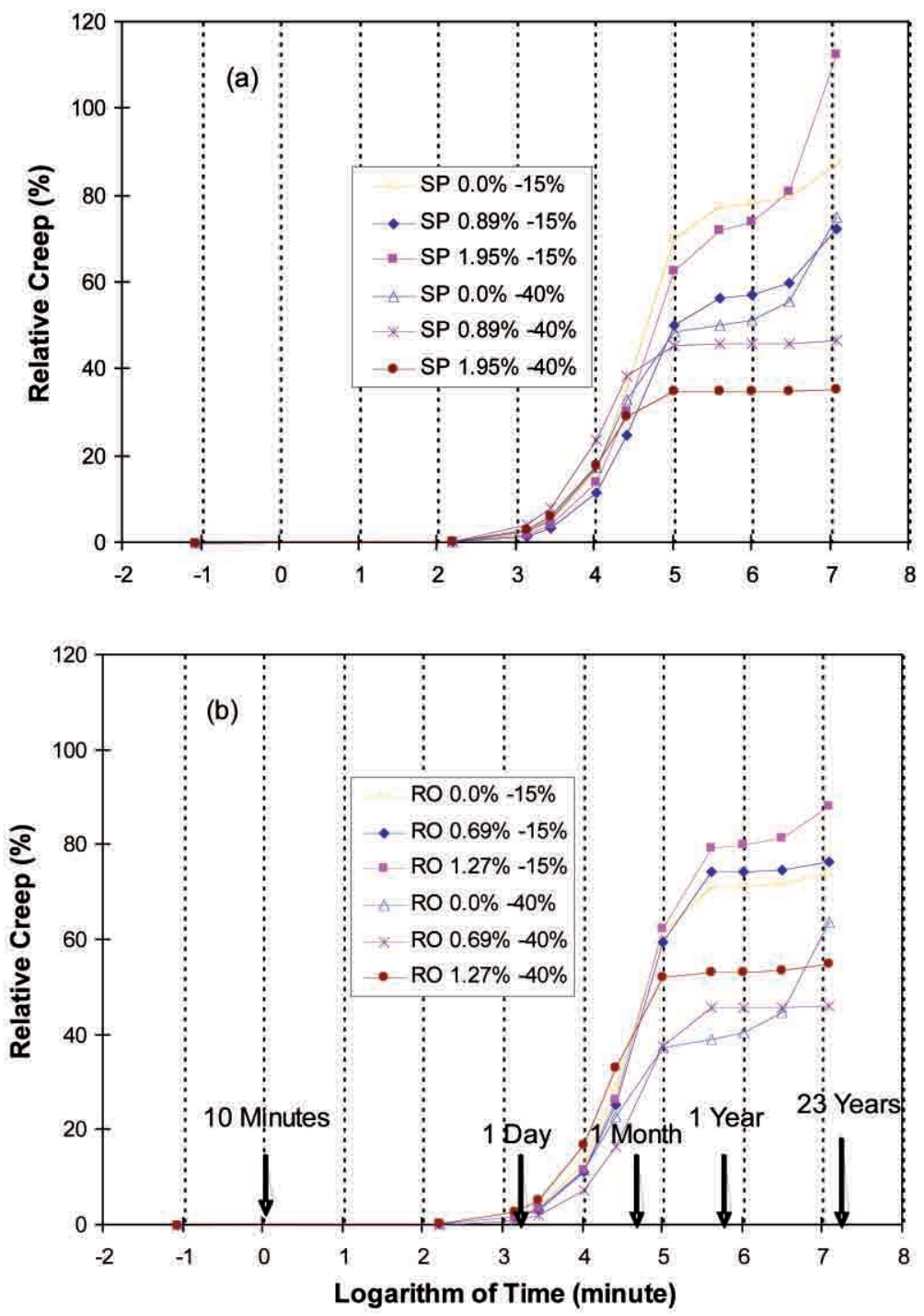

Figure 6. Predicted relative creep for southern pine (a) and red oak (b) strandboard under different borate and stress levels.

\section{Residual mechanical properties}

The residual mechanical properties (MOE and MOR) of different strandboard groups and controls under two loading stresses after two months are summarized in Table 1. Some southern pine and red oak strandboard samples showed decreases in MOE and MOR, but the others showed some increases in their mechanical properties. Strandboard panel treated with different levels of borate treatment behaved in the similar way. Further statistical analysis on residual properties showed that there was no significant reduction due to the variability nature of wood composites in their density and strength properties. This indicated that short period of duration (two-month in this study) under low flexural bending stresses (up to $40 \%$ ) did not significantly reduce load-carrying capacities of strandboard panels. 


\section{CONCLUSIONS}

Creep behavior of zinc borate-treated strandboard was investigated under constant environmental conditions. Strandboard from two species (southern pine and red oak) were treated with three borate levels and were tested for creep under $15 \%$ and $40 \%$ stress levels. The results showed that the borate treatment had significant effect on long-term creep performance of treated panels, and that the effect varied with wood species. There was no significant effect of creep loading on residual bending properties of treated strandboard under the stress levels used. The four-element spring-dashpot creep model fitted the creep data well. The predicted creep deflection for a 10-year loading duration under both $15 \%$ and $40 \%$ stress levels met the National Design Specification for Wood Construction despite of the noticeable borate treatment effect on creep.

\section{REFERENCES}

American Forest \& Paper Association (AF\&PA). 2001. National Design Specifications for Wood Construction. AFPA. Washington D.C.

American Society for Testing and Materials. 1999. Standard method of static tests of wood-based panels. ASTM D-1037. The ASTM book of Standard Vol. 4.09. Philadelphia, Pa.

Bach, L. 1993. On the rheology of OSB. Presented for duration of load performance Structural Board Association Workshop - February, 16- 18, 1993, Toronto, Ontario, Canada.

Cai, Z.; Fridley, K.J.; Hunt, M.O.; Rosowsky, D.V. 2002. New creep and recovery models of wood under high stress levels. Wood and Fiber Science 34(3):425-433

Cheng, J.R., L. Bach.; Zhao, N. W. 1994. Flexural creep of OSB exposed to various cyclic and constant relative humidity conditions. In proc. of IUFRO Annual Meeting International Wood Engineering Conference, July 5-7, 1994, Sydney, Australia.

Creffield, J.W.;Watson, K. 2002. Correlation between a laboratory bioassay and field trial conducted to determine the termiticidal effectiveness of bifenthrin. International Research Group on Wood Preservation, Doc. No. IRG/WP 02-20248.

Fridley, K. J.; Tang, R.C.; Soltis, L.A. 1992. Creep behavior model for structural lumber. $J$. of Structural Engineering 118(8):2261-2277.

Gardner, D.J.; Tascioglu, C.; Wålinder, M.E. 2003. Wood composite protection. In: Wood Deterioration and Preservation: Advances in Our Changing World. B. Goodell, D.D. Nicholas, and T.P. Schultz, Eds. American Chemical Society, Washington, DC., pp. 399-419.

Gittus, J.H. 1975. Creep, Viscoelasticity, and Creep Fracture in Solids. John Wiley and Sons, Inc., New York. Chapter 7.

Kirkpatrick, J. W.; Barnes, H.M. 2006. Biocide treatments for engineered wood composites using strandboard as a test platform. In: Proceedings, Wood Protection 2006 (H. M. Barnes, ed), Forest Products Society, Madison, p. 329-337

Laks, P.E. 2002. Biodegradation susceptibility of untreated engineered wood products. In: Enhancing the Durability of Lumber and Engineered Wood Products. Forest Products Society, Madison, WI. pp. 125-130. 
Laks, P.E.; Haataja, B.A .; Palardy, R.D.; Bianchini, R.J. 1988. Evaluation of adhesives for borate-treated flakeboards. Forest Prod. J. 38(11-12):23-24.

Laufenberg, T. L.; Palka, L.C.; McNatt, J. D. 1994. Creep and creep-rupture behavior of woodbased structural Panels. Forintek, Canada Corp. Vancouver, B.C.

Lee, J. N. 1999. Structural behavior of yellow-poplar LVL :Effect of veneer-joint designs and environmental conditions. Ph. D. Dissertation, Auburn University, Auburn, Alabama. 354p.

Lee, S., Wu, Q.; Smith, W. R. 2004. Formosan subterranean termite resistance of borate-modified strandboard manufactured from southern wood species: a laboratory trial. Wood Fiber Sci. 36(1):107118.

Leichti, R.J. 1986. Assessing the reliability of wood composite I-beams. Ph.D. Dissertation. Auburn University, Auburn, Alabama. 267p.

Leichti, R. J.; Tang, R.C. 1987. Effect of creep on the reliability of sawn timber and wood composite I-beams. Mathematical computation and modeling 12: 153-161.

Palka, L.C. 1993. An overview of bending creep and creep-rupture of waferboard panels : The Forintek Experience. In Proc. of the duration of load workshop, SBA, Toronto, Canada.

Pierce, C.B.; Dinwoodie, J.M. 1977. Creep in chipboard. Part 1. Fitting 3- and 4-element response curves to creep data. J. Materials Sci. 12:1955-1960.

Sean, T.; Brunette, G.; Cote, F. 1999. Protection of oriented strandboard with borate. Forest Prod. J. 49(6):47-51.

Soltis, L. A.; Winandy, J. E. 1988. Long term strength of CCA-treated lumber. Forest Prod. J. 39(5):64-68.

Winandy, J.E. 1995. Influence of time-to-failure on strength of CCA-treated lumber. Forest Prod. J. 45(2):82-85.

Yeh, M.C. 1990. Time-dependent structural behavior of wood composite panels. Ph.D. Dissertation. Auburn University, Auburn, Alabama. 215p. 